phisticated. The librarian who provides such guidance plays a major role in the learning process.

The character and quality of an institution of higher learning are shaped in large measure by the nature of its library holdings and the ease and imagination with which those resources are made accessible to members of the academic community. Consequently, all members of the faculty should take an active interest in the operation and development of the library. Because the scope and character of library resources should be taken into account in such important academic decisions as curricular planning and faculty appointments, librarians should have a voice in the development of the institution's educational policy.

Librarians perform a teaching and research role inasmuch as they instruct students formally and informally and advise and assist faculty in their scholarly pursuits. Librarians are also themselves involved in the research function; many conduct research in their own professional interests and in the discharge of their duties.

Where the role of college and university librarians, as described in the preceding paragraph, requires them to function essentially as part of the faculty, this functional identity should be recognized by granting of faculty status. Neither administrative responsibilities nor professional degrees, titles, or skills, per se, qualify members of the academic community for faculty status. The function of the librarian as participant in the processes of teaching and research is the essential criterion of faculty status.

College and university librarians share the professional concerns of faculty members. Academic freedom, for example, is indispensable to librarians, because they are trustees of knowledge with the responsibility of insuring the availability of information and ideas, no matter how controversial, so that teachers may freely teach and students may freely learn. Moreover, as members of the academic community, librarians should have latitude in the exercise of their professional judgment within the library, a share in shaping policy within the institution, and adequate opportunities for professional development and appropriate reward.

Faculty status entails for librarians the same rights and responsibilities as for other members of the faculty. They should have corresponding entitlement to rank, promotion, tenure, compensation, leaves, and research funds. They must go through the same process of evaluation and meet the same standards as other faculty members. ${ }^{1}$

On some campuses, adequate procedures for extending faculty status to librarians have already been worked out. These procedures vary from campus to campus because of institutional differences. In the development of such procedures, it is essential that the general faculty or its delegated agent determine the specific steps by which any professional position is to be accorded faculty rank and status. In any case, academic positions which are to be accorded faculty rank and status should be approved by the senate or the faculty at large before submission to the president and to the governing board for approval.

With respect to library governance, it is to be presumed that the governing board, the administrative officers, the library faculty, and representatives of the general faculty, will share in the determination of library policies that affect the general interests of the institution and its educational program. In matters of internal governance, the library will operate like other academic units with respect to decisions relating to appointments, promotions, tenure, and conditions of service. ${ }^{2}$

${ }^{1}$ Cf. 1940 Statement of Principles on Academic Freedom and Tenure; 1958 Statement on Procedural Standards in Faculty Dismissal Proceedings; 1972 Statement on Leaves of $A b$ sence.

${ }^{2}$ Cf. 1966 Statement on Government of Colleges and Universities, formulated by the American Council on Education, American Association of University Professors, and Association of Governing Boards of Universities and Colleges.

\title{
Standards for Faculty Status for College and University Librarians
}

Adopted by the Membership of the Association of College and Research Libraries, Dallas, Texas, June 26, 1971.

With publication increasing at an exponential rate, with the variety of forms of publication proliferating rapidly, with significant scholarly and information material appearing in all the world's languages, with the bibliographical apparatus of many fields and subfields becoming increasingly difficult to use, with the growing sophistication of library and information technology, and with the development of academic libraries into large and complex organizations, the work of the academic librarian has become highly specialized and demanding. 
The academic librarian makes a unique and important contribution to American higher education. He bears central responsibility for developing college and university library collections, for extending bibliographical control over these collections, for instructing students (both formally in the classroom and informally in the library), and advising faculty and scholars in the use of these collections. He provides a variety of information services to the college or university community, ranging from answers to specific questions to the compilation of extensive bibliographies. He provides library and information services to the community at large, including federal, state, and local government agencies, business firms and other organizations, and private citizens. Through his own research into the information process and through bibliographical and other studies, he adds to the sum of knowledge in the field of library practice and information science. Through membership and participation in library and scholarly organizations, he works to improve the practice of academic librarianship, bibliography, and information service.

Without the librarian, the quality of teaching, research, and public service in our colleges and universities would deteriorate seriously and programs in many disciplines could no longer be performed. His contribution is intellectual in nature and is the product of considerable formal education, including professional training at the graduate level. Therefore, college and university librarians must be recognized as equal partners in the academic enterprise, and they must be extended the rights and privileges which are not only commensurate with their contributions, but are necessary if they are to carry out their responsibilities.

The Committee on Academic Status of the Association of College and Research Libraries strongly endorses the formal recognition of the college or university librarian's academic status by all institutions of higher education and their governing bodies. It urges that the Association of College and Research Libraries and the American Library Association adopt as standards the following rights and privileges for all academic librarians:

1. Professional responsibilities and self determination. Each librarian should be assigned general responsibilities within his particular area of competence. He should have maximum possible latitude in fulfilling these responsibilities. However, the degree to which he has fulfilled them should be regularly and rigorously reviewed. A necessary element of this review must be appraisal by a committee of peers who have access to all available evidence.
2. Library governance. College and university libraries should adopt an academic form of governance. The librarians should form as a library faculty whose role and authority is similar to that of the faculties of a college, or the faculty of a school or a department.

3. College and university governance. Librarians should be eligible for membership in the academic senate or equivalent body at their college or university on the same basis as other faculty.

4. Compensation. The salary scale for librarians should be the same as that for other academic categories with equivalent education and experience. Librarians should normally be appointed for the academic year. If a librarian is expected to work through the summer session, his salary scale should be adjusted similarly to the summer session scale of other faculty at his college or university.

5. Tenure. Librarians should be covered by tenure provisions the same as those of other faculty. In the pretenure period, librarians should be covered by written contracts or agreements the same as those of other faculty.

6. Promotion. Librarians should be promoted through ranks and steps on the basis of their academic proficiency and professional effectiveness. A peer review system similar to that used by other faculty is the primary basis of judgment in the promotion process for academic librarians. The librarians' promotion ladder should have the same titles, ranks, and steps as that of other faculty.

7. Leaves. Sabbatical and other research leaves should be available to librarians on the same basis, and with the same requirements, as they are available to other faculty.

8. Research funds. Librarians should have access to funding for research projects on the same basis as other faculty.

9. Academic freedom. Librarians in colleges and universities must have the protection of academic freedom. Library resources and the professional judgment of librarians must not be subject to censorship.

To implement these standards, the Association of College and Research Libraries and the American Library Association will:

1. Publicize these standards to all colleges and universities and their libraries, all library schools, all library organizations, all higher education organizations, and all agencies which accredit academic institutions.

2. Seek to have these standards formally adopted or endorsed by all colleges and 
universities and their libraries, all library schools, all library organizations, all higher education organizations, and all agencies which accredit academic institutions.

3. Investigate all violations of these standards which are reported by members of the Association of College and Research Libraries. Such investigations will be coordinated and supervised by the Committee on Academic Status of the Association of College and Research Libraries.

4. Invoke the following sanctions against institutions of higher education which are found, after such investigation, to be in violation of any or all of these standards:

a. Publicize the violation and the institution concerned in CRL News and other appropriate publications. b. Refuse to accept advertisements in any ALA publication for positions at that institution.

c. Discourage its members from accepting employment at that institution, through notices in its publications and other means.

A reasonable amount of time-three to five years-should be provided college and university libraries which do not currently conform to any or all of these standards, to enable them to do so. However, no such grace period should be provided to libraries which currently do conform, either wholly or in part, and which seek to deny or withdraw any such rights and privileges.

\section{Norman Tanis Elected Vice President}

Norman E. Tanis, director of University Libraries at California State University, Northridge, is the newly elected vice-president of the Association of College and Research Libraries. Tanis received a total of 1,849 votes in the elections held late this spring. Richard Ducote, director for Instructural Resources at the College of DuPage, Glen Ellyn, Illinois, polled 1,081 votes. Both Tanis and Ducote have long been interested in and associated with twoyear colleges and their nominations recognized the increasing importance of junior and community college librarians in ACRL.

After obtaining a Master of Arts in Library Science and an M.A. in history from the University of Michigan, Tanis became reference librarian and later head librarian at Henry Ford Community College, Dearborn, Michigan. From 1966 through 1969 he held the position of director of libraries and professor of $\mathrm{Li}$ brary Science at Kansas State College, Pittsburgh, Kansas. He has been at California State University, Northridge, formerly known as San Fernando Valley State College, since 1969.

Tanis received his undergraduate training at Calvin College. In addition to his other degrees from the University of Michigan he was awarded an M.A. in education from that institution in 1961. Tanis has been a member of the ACRL Board of Directors since 1967. He also served in this capacity from 1962 to 1965 . $\mathrm{He}$ has been chairman of the Junior College Libraries Section, chairman of the Committee on Standards and Accreditation, a member of the Editorial Board of College \& Research Libraries, and a member of the ACRL-Asso- ciation of Research Libraries Joint Committee on University Libraries Standards. He has also held positions on various ALA committees and has been an ALA representative to other educational and professional organizations.

As vice-president Tanis will serve as a member of the New York Conference Planning Committee, a member of the ALA Budget Assembly, and chairman of the ACRL Planning Committee. He will become ACRL's thirty-fifth president at the close of the Las Vegas Conference in June of 1973.

The results of the section and subsection elections are as follows: (Elected officers are shown in italics.)

\section{COLLEGE LIBRARIES SECTION}

Vice Chairman/Chairman-Elect: Father Jovian Lang, librarian, University of South Florida, Tampa, Florida (385); Richard C. Quick, director of libraries, State University of New York, College of Arts and Science, Geneseo, New York (514). Secretary: Carol C. Henderson, reference and circulation librarian, George Mason College of the University of Virginia, Fairfax, Virginia (388); Beverly M. Johnson, chairman, Catalog Department, San Diego State University, San Diego, California (487).

\section{JUNIOR COLLEGE LIBRARIES SECTION}

Vice Chairman/Chairman-Elect: Louise Giles, dean of Learning Resources, Macomb County Community College, Warren, Michigan (279); W. Christian Sizemore, acting academic dean, South Georgia College, Douglas, 